\title{
"Insufficiency" and Upbringing. The Role of the Family in Shaping Humanity
}

When we look at the life of the human person, we surely notice that, at almost every stage, this life is marked by certain "insufficiency", lack, or weakness. We strive to achieve a particular goal in the form of material, spiritual, cultural, or intellectual values, but always discover some insufficiency, such as a lack of the right knowledge, manual or intellectual abilities, or even a complete inability to overcome a certain obstacle. One could make a long list of activities and institutions which support us on our way to cope with these insufficiencies or shortages. They include: family, school, university, the Church, various educational organizations, the media, etc. They all support people in acquiring the necessary knowledge and discovering talents and abilities at various stages of human life. It can be said that they are all at the service of man's humanity.

A special stage of this insufficiency is the childhood, where the child is at the mercy of adults. In fact, one of the thinkers, Gustav Siewerth, speaks directly about the "metaphysics of childhood", which is often forgotten 
by adults, who are assured of their self-sufficiency. ${ }^{1}$ However, all people, including adults, struggle with their limitations on a daily basis. Therefore, in this short article, I propose to pause for a moment and ponder about the meaning of "insufficiency" for both the child and the educator, especially the parents to whom the child is entrusted. For as we often see, the truth comes from the heart of experience, and drama has a power to transform and can even be a blessing.

\section{1. "Insufficiency" as a challenge}

In the $16^{\text {th }}$ chapter of his book, the prophet Ezekiel reaches for a metaphor of education while revealing the beginnings of the covenant of God with Israel. In order to describe the situation of Israel before the conclusion of the covenant, the prophet uses the commonly known concepts referring to the birth of a child who, coming into the world, does not find parental love. We read: "On the day you were born your cord was not cut, nor were you washed with water to make you clean, nor were you rubbed with salt or wrapped in cloths. No one looked on you with pity or had compassion enough to do any of these things for you. Rather, you were thrown out into the open field, for on the day you were born you were despised." (Ez 16, 4-5) We see here a series of dramatic negations, which describe the state of rejection of a newly born child, who is completely dependent on the care of others and doomed to die, if no one takes care of it. We can describe this situation with such words as uncertainty, powerlessness and fragility.

Uncertainty, or an existence which cannot secure itself in its own being, does not have a warranty and relies on sensitivity and commitment of others. For a child does not exist only as a fruit of the engagement of bodies in a sexual intercourse, but also because of the obligation given day by day for nine months by the mother, in whose womb it grew, united with her, but at the same time different from her; close to her but at the same time mysteriously strange.

Powerlessness is another word that describes the situation because an infant cannot talk about its most elementary needs. Completely dependent

\footnotetext{
1 Cf. G. Siewerth, Aux sources de l'amour. Métaphysique de l'enfance, Paris 2001.
} 
on the world and others, the child is exposed and vulnerable, without a possibility of defense: "you were thrown out into the open field."

Finally, there is fragility, that is, exposure to injury or even destruction. It is this fragility in the beginnings of life that can be a source of wounds which are more lasting in the memory of the body than those that we consciously experience in adulthood. The trauma of the early childhood leaves a permanent mark on the human psyche.

The three words above that illustrate the insufficiency of a child, occur again and again in direct confrontation with everyday life. Numerous cases of child abuse, even of very young children, by their parents, confirm this situation.

But the child is not only an insufficient being. The child is, first and foremost, a human being of promise, a person present to the sufficient extent to demand respect and hidden in a way which brings about unlimited trust, similar to the act of faith. This demands from us a different understanding of human "insufficiency"; not through uncertainty, powerlessness and fragility, but through possibilities that extend into the future and associated hopes. All that begins is weak and sensitive like a spring flower on a tree, which nevertheless holds a promise of beautiful fruit. In order to pass on a life and to educate, it is necessary to enter the space of hope, which is distant from cold calculation and often gets quickly erased by our technical capabilities. One must accept that it is not possible to know everything and agree to a risk of the future, a time of possibility without a full guarantee of success, and surprises awaiting at upcoming events.

This "insufficiency" of man, which appears to be a weakness and a promise, is a great challenge. In the message of the prophet Ezekiel, God says: 'Live!' Yes, I said to you... I spread My skirt over you and covered your nakedness." (Ez 16, 6-8). This call is unconditional. Man cannot adopt an attitude other than to take up the process of growing in humanity. With regard to the child, this imperative is a challenge for educators, the parents in the first place. How can they respond to the child's needs? Children expects their parents to "cover their nakedness" and enable them to live. And to tell your child: "Live!", means to provide them with opportunities and the means necessary to grow in humanity.

Education is, thus, a task which consists in helping children overcome what is weak and insufficient, and enriching moral, intellectual, and cultural 
values. It should free the child from what is weak and fragile, and lead to a reassured life by offering goods that will effectively overcome original imperfections. Education should relieve children from the fear caused by the contrast between their insufficiency and weakness, and the surrounding world, and give them a certainty provided not only by material goods such as bread, clothes, and home, but also by abilities that the children can gradually discover and develop. Thanks to them, the child moves from a situation of dependence to increasing autonomy, overcomes weaknesses and becomes more and more capable of taking initiative and responsibility.

But before the child is able to say the first words and overcome his or her frailty, for the parent, especially for the mother, he or she is above all a recipient and listener. However, the words spoken to the child and the gestures make sense if they are accompanied by love. No good offered by a parent is able to help overcome the child's weakness if it is not also an expression of love and generosity. The good that the educator gives cannot be subjected to the law of commercial exchange but should express the commitment of love and generosity.

\section{2. "Insufficiency" as an experience}

Insufficiency is also an experience that both the pupil and the educator face. It would be too simplistic, and indeed mistaken,, to notice it only in the child, while emphasizing the strength and possibilities of the educator. Insufficiency affects both parties.

Education is a reality that connects generations in the history of mankind. In this sense, it touches the feebleness of life, subjected to the law of time and passing to make room for others, as expressed in the saying: "the birth of a child is the death of the parents." A generation gap, which is present in the history of every generation, illustrates this situation even better, when two kinds of love meet; the educator's love, which is demanding, and the child's love, which awaits acceptance. Both are exposed to risks that result from freedom. Therefore, the educator, instead of showing the child certain goods, should open up the beauty of life for the pupil, the space of good and values. For a child who is growing up, and a young person who slowly discovers his or her autonomy do not know fully what it means to be self- 
sufficient. They gradually discover it by learning more about themselves and by looking at their educators' example. The educator must make sure that the goods that are offered do not eliminate or exceed the need to be selfsufficient. On the other hand, they must see to it that their lack does not lead to resignation or emptiness. The educator, as well as the pupil, experience weaknesses and situations that put the highest ethical values to the test and direct confrontation, in various circumstances. Therefore, the task of the educator is to seek answers for themselves, and for the ones who are not able to find them on their own yet, and to change "insufficiency" and fragility into opportunities and hopes that give rise to humanity.

These are educators that experience, more than anyone else, the insufficiency and painful discord between good intentions and their realization, between what they did, believing that it was good, and what they managed to do in the process of education, for they often see that the effort put into education does not find a response, and that the love they offered is considered obtrusive and is rejected by those to whom it was offered. As Maurice Blondel says: "What would I not give to overcome imperceptible objections, to bring down barriers, which I do not try to break, but whose existence I surmise, to ignite a spark and touch those I have before me and from whom I feel irretrievably separated!"2

Today, we notice a crisis in education, which is often compared to the crisis of values, especially the spiritual ones. It seems, then, necessary to look at the third dimension or the meaning of the term "insufficiency" in education, namely "insufficiency" as grace. In this case, it is the analysis of the problem not only from the point of view of the pupil's appeal to the educator, or as an experience which tests the educative love, but an attempt to see insufficiency as a source of grace and blessing.

\section{3. "Insufficiency" as grace}

Education is a space where mutual human love and God's love for people meet and deepen. But one cannot overlook the truth that. although love is directed towards what is weak and fragile, and it is often fragile itself, yet it is the name of God Himself. "God is love" - teaches St. John (1 John 4:16).

2 M. Blondel, L'Action, Paris 1950, p. 243. 
Man was called into existence because of love. and for love. This truth was expressed by the Second Vatican Council. In the constitution Gaudium et spes, we read that man is "the only creature on earth which God willed for itself," and that this man "cannot fully find himself except through a sincere gift of himself." It is in the light of this truth that we can learn the true scope of this "insufficiency" whose expression is the helplessness of a child totally dependent on the love of adults, especially parents. This insufficiency is not absurdly random, nor is it an anonymous gift of life. It is a promise that God will make us his children. The act does not exist by itself, and it does not demand the right of existence for itself, but is embraced by the love that gave birth to it. The wealth of "insufficiency" comes from realizing the truth that we are created by God, from whom "all fatherhood in heaven and on earth is named." In this light, it is also necessary to fully accept the promise that each child brings to this world. This is because to be a child means to entrust one's hopes to someone, and to be an educator means to be available to the nascent hope, and to shape it through educational work. Thus, the weakness and fragility of the nascent and growing life is the ability to draw and fill oneself with the values flowing from the source, which is the creative Love of God embracing every human being.

\section{4. "Insufficiency" as a challenge and gift for the family}

Parents play a fundamental role in the whole process of upbringing and all tasks and challenges connected with it. They are the first educators because they are parents. The Second Vatican Council reminds us about it: "Since parents have given children their life, they are bound by the most serious obligation to educate their offspring and therefore must be recognized as the primary and principal educators." ${ }^{5}$ This is also emphasized many times by John Paul II, who in Familiaris consortio says straightforwardly: "The right and duty of parents to give education is essential, since it is connected with the transmission of human life; it is original and primary with regard to the educational role of others, on account of the uniqueness of the loving

\footnotetext{
Second Vatican Council, Gaudium et spes, 24. John Paul II, Letter to Families, Vatican 1994, 9. Second Vatican Coulcil, "Gravissimus educationis", 3.
} 
relationship between parents and children; and it is irreplaceable and inalienable, and therefore incapable of being entirely delegated to others or usurped by others." And in the Letter to Families, he adds that education should be done primarily in the family, because "the family is the first and the most important ... it is a path from which man cannot withdraw."

Parents are entrusted with the humanity of their children because bringing up children is the bestowal of humanity, that is, an ongoing and dynamic process of giving birth in a spiritual sense. The commitment of love in the conjugal act, and the commitment given day after day within nine months by the mother, in whose womb not only is the child's body formed but also the whole personality, naturally complemented in the parental upbringing. Building a community of love that a family should be, the parents are the first to transmit two fundamental truths that man is called to live in truth and love, and that everyone finds fulfilment through a sincere gift of self. ${ }^{8}$ Raising a child is forming the child's attitude to "be" rather than "to have", so that the child could "be" not only for himself or herself, but also for others. For, as John Paul II teaches: "Children must grow up with a correct attitude of freedom with regard to material goods, by adopting a simple and austere life style and being fully convinced that "man is more precious for what he is than for what he has." It is worth emphasizing here how relevant the words of the Pope are today, when parents often become "slaves" of the whims of their children, and how we should return to them and practice them anew. For parents, to educate means to show the authentic good and teach this good. As Fr. Józef Tischner said: "A person who was brought up well is used to the good: prays frequently, gives to charity, has a friendly smile when meeting people, etc." 10

Therefore, for parents, this "insufficiency" of the child and his or her upbringing is also a gift. The child, as the Second Vatican Council teaches, is for them "the most precious gift." "Education then is before all else a reciprocal "offering" on the part of both parents: together they communicate their own mature humanity to the newborn child, who gives them in turn

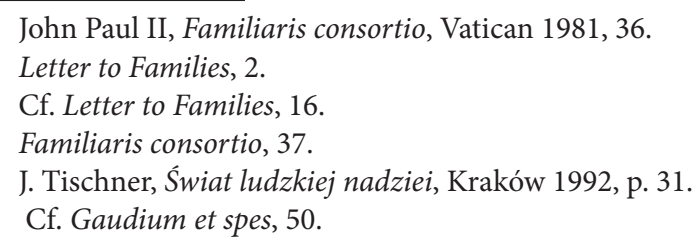


the newness and freshness of the humanity which it has brought into the world." 12 Taking up educational effort for their children, parents learn again what it means to "be" human and how to give this wealth to their children; not only what it means to "have" children, and also "own" certain goods that are important in everyday life.

This mutual relationship, which takes place between parents and their children, although it is sometimes difficult and requires effort or even sacrifice, thus becomes a space for mutual enrichment and a source of humanity, which is constantly discovered. It is possible only in the family, because of the natural bonds connecting parents and children, enabling mutual trust, including "insufficiency". It is their common journey, whose image can be found in the poetic vision of John Paul II in The Roman Triptych. "Allow me to wet my lips in spring water, to feel its freshness, reviving freshness ... if you want to find the source, you have to go up, against the current." ${ }^{13}$ We see here the discovery of humanity by the parents themselves and through them, by the child. Discovering its source, they find together, again and again, its "refreshing freshness". This, in turn, constitutes their common wanderings, often against the current of weakness and insufficiency, along the paths of everyday life, in order to find this unique source. Therefore, presenting The Roman Triptych, Cardinal J. Ratzinger says that John Paul II's view of the source is a view that shows who a human person really is. "In this very concrete historical event, which seems to distance us completely from the great visions of creation from the first part of Triptych, the beginning and the end of everything clearly emerges, the link between descent and climbing, between source, journey and goal: we recognize God, who offers himself, who is both the beginning, the way and the goal. This God is revealed through creation and history. He is looking for us in our sufferings and our questions. He shows us what it means to be human: to offer ourselves in love, because it makes us similar to God. / ... / The love that sacrifices itself is the mystery of the beginning, that is why and when we love, we also understand the mission of all creation and find the right way."14

\footnotetext{
12 Letter to Families, 16.

13 Jan Paweł II, Tryptyk rzymski, Kraków 2003, p. 11.

14 Benedykt XVI, J. Ratzinger, Jan Paweł II mój umiłowany poprzednik, Częstochowa
} 2007, p. 63. 
Modern man, especially the youngest and most vulnerable in a confrontation with his or her fragility and "insufficiency" in the realities of everyday life, seems, more than ever before, in need of guides who will show them authentic humanity. Parents, who in spousal love are the source of human existence, are called to make their humanity the scope and likeness of the image which the Creator inscribed in the moment of creation.

\section{Bibliography}

Sobór Watykański II, Konstytucja duszpasterska o Kościele w świecie współczesnym Gaudium et spes.

Sobór Watykański II, Deklaracja o wychowaniu chrześcijańskim Gravissimum educationis.

Jan Paweł II, Adhortacja apostolska o zadaniach rodziny w świecie współczesnym Familiaris consortio, Watykan 1981.

Jan Paweł II, List do rodzin, Watykan 1994.

Jan Paweł II, Tryptyk rzymski, Kraków 2003.

Benedykt XVI, J. Ratzinger, Jan Paweł II mój umiłowany poprzednik, Częstochowa 2007.

Blondel M., L'Action, Paris 1950.

Siewerth G., Aux sources de l'amour. Métaphysique de lenfance, Paris 2001.

Tischner J., Świat ludzkiej nadziei, Kraków 1992. 
